Special Issue of Democratization: On the State of Democracy, Julio Faundez (ed.)

\title{
Markets, States and Democracy: Patron-Client Networks and the Case for Democracy in Developing Countries
}

\section{By}

\author{
Mushtaq H. Khan \\ Department of Economics, School of Oriental and African Studies, University of \\ London.
}

\section{Summary}

The debate between modernization theory and its opponents is over. Neither evidence nor argument can support the claim that authoritarianism is necessary for economic development. However, is democracy necessary for development, as opposed to obviously being desirable on other grounds? The evidence on how democracy actually operates in developing countries raises important questions about the relationship between markets, states, and democracies. In particular, the role of patron-client networks in these countries questions the relevance of the standard arguments made for the positive economic effects of democracy in developing countries. There is, however, an argument from the neo-Weberian school that claims that democratization can begin to undermine the patron-client relationships (neopatrimonialism) that impede development. But in fact, there are powerful structural reasons why this is not likely to happen. Economic characteristics of developing countries make patron-client politics both rational for redistributive coalitions and effective as strategies for achieving the goals of powerful constituencies within these coalitions. These are unlikely to be affected by democratization. The evidence strongly supports our analysis. If this is right, and if many types of patron-client politics are damaging for development, democratization is unlikely to accelerate economic development. The case for democratization has to be made on other grounds. 
Democracy is a system of rules for electing the executive and the legislature that constitutes the government of a society through a process of competitive and contested elections. The relationship between democracy and the developmental performance of markets and states, particularly in the developing world, has been at the heart of some of the most intense debates in economics, political science, and development studies. On the one hand, the evidence is overwhelming that rich countries can sustain viable democracies, while poor countries often cannot. The data that shows that more developed economies have more sustainable democracies is about as conclusive as data in social science can be. The debate has instead been over the extent to which democracy allows or is even necessary for economic development. On this critical question, political opinion has swung dramatically away from the modernization theories that held sway till two decades ago, but on many substantive questions, the jury is still out.

The historical evidence can be interpreted in various ways depending on the samples chosen and the period examined, but taken as a whole, the evidence on the impact of democracy on development is inconclusive. There are enough exceptions on both sides of the argument to suggest that neither democracy nor authoritarianism is a precondition for development. We can find examples of rapid growth in the set of countries that were democratic as well as in the set that was authoritarian. Similarly, we can find (unfortunately even more) examples of economic stagnation in the set of countries that were democratic as well as in the set that was authoritarian. Since most people would agree that democracy is better than its absence, this evidence can be interpreted as an argument for democracy. However, the evidence can also be interpreted to mean that democracy is not necessarily a precondition for economic development. It follows that the policy priority given to democratization in recent years may be diverting us from more important priorities that may be necessary to achieve the prosperity required for making democracy both more sustainable and capable of delivering real decision-making powers to societies. In this article, I examine some important but often neglected aspects of the two-way relationship between democracy and economic development by looking at how democracy affects and is affected by the operation of markets and states in developing countries. This, in turn, leads us to examining the implications of these observations for political reform strategies in developing countries.

To understand how democracy operates in developing countries, our starting point will be to argue that we need to look more closely at why political contestation in developing countries is organized through the mobilizations of patron-client factions, rather than through the mobilization of class or economic interest groups. We argue that these political features of developing countries are intimately connected to the underdevelopment of economies, the limited scope of viable capitalist economies in developing societies, and the inevitable social transformations that these societies are experiencing. The factional mobilizations that are characteristic of this period can, and often do, have negative effects on economic development and political stability. This could explain not only why democracies are vulnerable in developing countries, but also why economic growth is often so fragile.

However, factional conflicts and contests over resources do not necessarily have to lead to either economic stagnation or the breakdown of democracy. In some cases, democracy may be a viable mechanism of managing these conflicts, and factional 
conflicts can drive economic growth in some contexts. The economic outcomes of democratic management of factional conflicts are therefore not well-defined without a further examination of the specific patron-client networks and factions that are involved in particular countries. The example of India demonstrates how factional politics operating through democratic institutions can allow a country to continue its transition to a specific type of capitalist economy. While some countries such as India have done well with democracy, the bigger policy question is about the viability of the democratization reforms that are being promoted across the world by international agencies. Here, I argue that without understanding the role of patron-client factions in the politics of developing countries, programmes of democratization are often missing the point, even from the narrow perspective of deepening the entrenchment of democracy. The first of the following sections reviews a number of conventional theories linking democracy to development and points out how these theories are undermined by the presence of factional politics in developing countries. The next section presents some of the extensive evidence showing that developing country democracies are in fact characterized by intense patron-client politics and are quite different in their operation from advanced country democracies. The third section presents an alternative way of explaining the dominance of patron-client politics in developing countries based on structural features of their economies. This analysis has significant implications both for the debate between modernization theory and its opponents and for the support for democratization coming from theories of neopatrimonialism that have become very influential as part of the good governance agenda. The last section summarizes some of the conclusions.

\section{Conventional Theories of Democracy and Development}

Conventional theories of democracy and development present abstract arguments linking democracy with economic outcomes. Their general argument, however, is undermined if we bring into the analysis specific features of developing countries, in particular, as will be explained below, the issues of patron-client networks and factional politics. The case for democracy has to be built on other grounds, and the policies that are required for making democracy viable need to be identified using other more appropriate theories. It is therefore useful to begin with a brief review of the main types of arguments that are conventionally presented about the links between democracies on the one hand and the operation of markets and states on the other. There are three major arguments linking democracy to the more efficient operation of markets and states, which consequently has a positive effect on developmental outcomes. The first argument focuses on the better use of information in democracies. This, in turn, allows for better preference identification, better policy and project choice or simply disaster avoidance. The second argument focuses on the procedural advantage of democracy in allowing more rapid institutional change in the direction of greater efficiency. The third argument focuses on the advantage of democracy in maintaining the stability of the political system and of property rights, both essential for economic development. I summarize each argument, in turn, and consider how the patron-client political characteristics of developing countries can undermine them. Finally, I consider, in a later section, a fourth, neo-Weberian argument, which claims that democracy is essential for overcoming patron-client politics. 
The most obvious argument linking democracy with development is that the competition for office reveals information for current and future policy-makers that could not otherwise have been generated. We have to distinguish here between information that allows preference identification (what do the 'people' want), information that enables better policy and project choice, and information that allows governments to avoid major catastrophes.

The preference identification argument is the least convincing. It is not at all clear, even in theory, what democracy can do to identify 'social' preferences. The problem is that a single set of social preferences may not exist, so that there is no simple sense in which we can discover them. Different groups and classes in society may have incompatible preferences, and the outcome of voting may depend on the details of voting procedures, or differences in the organizational power of different groups and their ability to set agendas. ${ }^{1}$ The distribution of organizational abilities is a particularly important factor. The superior organizational power of patron-client factions in developing country democracies can help to explain why electoral competition does not in general result in government preferences being set by the poor even though they constitute huge majorities. There are, of course, exceptions. Economic policy in some developing country democracies is more decidedly propoor. Some arguments about the desirability of democracy extrapolate from specific examples of pro-poor state policies in democracies (the state of Kerala in India is a particular favourite) to the general conclusion that democracy empowers the poor to influence or even determine state policies in ways that help to develop the capabilities of the poor to participate in development. ${ }^{2}$ But in fact, a comparison of Kerala with equally democratic neighbouring Indian states suggests that the emergence of propoor economic policies depends on many contingent features of the factional politics of particular states rather than on democracy in general. Equally, far less democratic states like China (under Mao) or South Korea (in the 1960s) achieved higher scores on health and education relative to their comparators at similar per capita incomes. Thus, while policy preferences that reflect majority interests can emerge through democracy, the latter is neither necessary nor sufficient for this result.

The second type of information argument is that democracy provides greater scrutiny for policy and project choices and therefore results in better economic outcomes. This is theoretically a more plausible argument, but even here, the linkage is ambivalent. Clearly, bureaucrats in charge of project selection need to have incentives for making the right choices and should be accountable if they make mistakes, but democracy (as a system for selecting and rejecting politicians) may not be either necessary or sufficient to achieve this. Even from a narrow information perspective, having more points of scrutiny does not necessarily lead to better policy or project choices. In particular, if the cost of collecting and assessing information is high, increasing the degree of scrutiny could result in bad outcomes. ${ }^{3}$ If we add to this information perspective the observation that the scrutiny in real developing country democracies is effectively being practised by political factions who are likely to have sectional interests, the outcomes of democratic scrutiny clearly depends on specific local factors. This qualified scrutiny can often be better than the alternative, but need not necessarily be so. 
The most powerful variant of the information argument is that democracy produces information about impending disasters, and therefore, major disasters can be avoided. Drèze and Sen famously argued that famines never happen in democracies because the press and the opposition ensure that even the most self-interested government takes steps to avert major disasters. ${ }^{4}$ But major disasters need to be defined. Many democratic developing countries can live with festering poverty and high numbers of deaths due to nutrition deficiency as a 'normal' state of affairs. Nor is it strictly true that no democratic country has suffered from a famine. The 1974 famine in Bangladesh happened under a democratic regime, which turned increasingly authoritarian as it failed to manage the economy and polity. Nevertheless, disaster avoidance is arguably the most convincing information-based argument in favour of democracy.

\section{Democracy as A Regime that Ensures Efficient Institutional Change}

A somewhat more sophisticated but, ultimately, unconvincing set of arguments in favour of democracy comes from the transaction cost analysis of Douglass North. The argument here is that economic efficiency requires the evolution of economic institutions and property rights to reduce transaction costs in the market. All institutional changes involve winners and losers. Institutional changes that are efficient from the perspective of economics are those where the winners gain more than the losers lose. If our political institutions ensured that only this type of institutional change could happen, these political institutions would promote economic efficiency. North argues that for all its imperfections, a democratic system with low political transaction costs (the costs of organizing coalitions and reaching compromises between them) is most likely to achieve this. By reducing the cost of political negotiation, a democracy could assist in negotiating compensations to losers that would allow their opposition to efficient policy or institutional changes to be overcome. ${ }^{5}$ Equally, inefficient institutional changes or policies would be rapidly blocked by coalitions of losers because their loss would be greater than the potential gain of the proposers of the inefficient policies. Democracy would allow potential losers to offer enough to proposers of bad policies to stop these policies being implemented. The possibility that democracy can assist in introducing efficient policy and institutional change and to stop bad policies being implemented is one of the underlying arguments in support of democratization in the good governance reforms that developing countries are being encouraged to undertake. ${ }^{6}$

However, as North himself points out, even the most democratic political institutions are unlikely to approach zero transaction costs. When transaction costs remain high, the cognitive models of participants and their relative bargaining power will matter very much in determining the types of institutional changes that are negotiated and these outcomes need not enhance efficiency. ${ }^{7}$ In fact, the qualification is even stronger than North admits. Given very large differences in the political power of factions, there is no necessity for winners to offer compensation to losers. Indeed, historically, winners have rarely compensated losers, and democracy has never really functioned as an efficient institutional system to organize compensation. Rather, both democracy and authoritarianism have functioned as mechanisms for managing conflicts and suppressing losers. ${ }^{8}$ Occasionally, democracies have achieved efficiency-enhancing institutional changes in developing countries, but when they have, this was not achieved through the efficient compensation of losers, but rather through ruling 
factions using a combination of obfuscation and divide and rule tactics against the opponents of reform to achieve their objectives. ${ }^{9}$ More often, democracies in developing countries have found it difficult to organize efficiency-enhancing institutional changes because losers could organize resistance through alliances with powerful factions. But authoritarian regimes did not necessarily perform better either. Some authoritarian regimes did find it easy to override resistance to efficiencyenhancing institutional changes, but many others found institutional change just as difficult to organize as democracies. Nevertheless, we can conclude that if we are not close to a world with zero political transaction costs, there is no reason to expect democracies to achieve efficiency-enhancing institutional changes faster than authoritarian regimes.

Democracies as Systems that Ensure Political and Economic Stability

A recent restatement of the argument that democracies are inherently stable has come from Olson, who introduced the metaphor of stationary and roving bandits to analyze the predatory tendencies of states. ${ }^{10}$ In Olson's stylization, the worst conditions of rule are those where societies face the predation of rulers behaving like roving bandits. Roving bandits by definition take a short-term view and have no incentive to limit their plunder. Development outcomes are dire. Things improve markedly when rulers who are roving bandits settle down and become stationary bandits. Although still predatory, these rulers take a longer-term view because they will remain in place for a long time, and consequently they have an incentive to moderate their extraction. A high rate of extraction can shrink the economy to the extent that the rulers' 'tax' take over time actually falls. Since stationary bandits will want to maximize their tax take over time, they have an incentive to reduce the rate of taxation so that social output can rise, and the total tax they collect is maximized. While the higher social output is a great improvement, the rule of stationary bandits suffers from periodic crisis due to the absence of rules to deal with succession. The transition from one ruler to the next is marked by uncertainty and the frequent outbreak of civil war. Democracies end this uncertainty and provide rules for the smooth transfer of power. In addition, democracies can result in a further reduction of taxation. Even though the majority can tax the minority, since the tax benefit has to be spread across the majority, each individual within the ruling group get very little and the incentive to organize taxation falls. The result is an even greater stability of property rights and political systems. An inherent problem with Olson's approach is that taxation is always seen as predatory above a minimum level required to provide basic public goods, so that it is always assumed that less taxation is better. Nonetheless, even in terms of Olson's own logic, there are limitations to his argument.

While Olson supported the emergence of democracies in developing countries, he was less sanguine about the role of democracy in advanced countries where democracies have matured. In the advanced countries he was more familiar with, Olson recognized that although democracy can theoretically limit the predation of the state, it could also create opportunities for non-state interest groups to increase their rent-seeking activities. Thus, in the USA, Olson saw democracy as a much more problematic system through which interest groups lobbied for special benefits to the detriment of the collective interest. He argued that the longer democracy operates, the higher the number of these special interest groups and the more sclerotic mature democracies become. Democracies occasionally require a shake-up to destroy the growing power 
of these special interest groups. ${ }^{11}$ Indeed in Olson's view, the destruction of special interest groups in Germany and Japan before, during, and after the Second World War through a number of very undemocratic processes helped to explain the subsequent dynamism of these two economies in the post-war period.

Whatever we make of this particular explanation for the post-war successes of Germany and Japan, Olson is wrong to think that interest group-driven redistribution is a problem faced only by mature democracies. In fact, the factional competition that characterizes developing country democracies is, if anything, more intense than the interest group competition in advanced country democracies. The choice in developing countries is in fact between different combinations of predation, factionalism, and clientelism. Movements towards or away from greater democratization can therefore have net effects that are very specific to the factional structures of particular countries. In some cases, democratization could reduce wasteful predation, in others it could result in greater waste by increasing factional rent-seeking activities. Moreover, Olson has no satisfactory explanation for why South Korea or Taiwan achieved economic and political stability in the 1960s and 1970s apart from the observation that they were stationary bandit states. However, other stationary bandit states failed to achieve this degree of success. Thus, in the case of developing country states no less than in advanced ones, we need to look more closely at the structure of interest groups and factions to be able to explain how democracy or authoritarianism worked to enhance or diminish economic and political stability.

\section{The Evidence}

From the very large body of evidence and empirical work in this area, I will point to some of the evidence that justifies questioning conventional wisdom. The first type of evidence comes from cross-sectional data on the economic characteristics of democratic and authoritarian countries. The one uncontested piece of evidence in an area where much of the empirical evidence and analysis is highly contested is that richer countries are more likely to be democratic than poorer ones. This has been emphatically demonstrated in many cross-sectional studies, including the extensive statistical study of 141 countries over the period 1950-1990 conducted by Przeworski et al and by Barro in his work on economic growth. ${ }^{12}$ Przeworski et al show that, in the long run, per capita income is the best predictor of democracy, and that other possible variables, including, in particular, dominant religions, colonial and political history, and ethno-linguistic and religious fractionalization do not add much to the power of per capita income to predict the likelihood of democracy. Statistically, we are also more likely to observe high per capita incomes leading to democratization rather than the other way around. ${ }^{13}$ However, when it comes to explaining why richer countries are more likely to be democratic, statistical analysis on its own offers much more limited insights. Przeworski et al reject the simplistic modernization thesis that argues that democracy will follow once economic development has been achieved. Their argument against this position is based on the observation of a significant number of relatively rich countries that remain authoritarian. These contrary examples show there is no consistent internal mechanism that ensures a transition to democracy as countries become richer. 
Instead, they propose a statistical selection mechanism that is more consistent with the historical observations. They suggest that when rich countries become democratic (through whatever mechanism) they have a higher probability of remaining democratic, while poorer countries who make an early transition to democracy are more likely to revert back to authoritarianism. ${ }^{14}$ This can explain why poor countries are statistically more likely to be authoritarian and rich countries more likely to be democratic, even without any mechanism to ensure that economic development will lead to a transition to democracy. Nevertheless, even if we say that rich countries are more likely to remain democratic regardless of how they become democratic, we still need to identify the factors that can explain why this should be the case. While the authors do not suggest specific mechanisms, they suggest that this could be because greater prosperity reduces the severity of distributive conflicts (which undermine democracy) and higher levels of education makes it easier to operate democratic procedures. But they agree that the mechanisms that make democracies in rich countries stable and democracies in developing countries vulnerable are not easy to identify with statistics alone. ${ }^{15}$

A second and very different type of evidence about the operation of democratic systems in developing countries is provided by comparative case studies. This kind of evidence does not allow the inclusion of every country for which we have data, in the way that cross-sectional regression analysis does. But what they lack in breadth, these case studies make up in depth. In particular, they allow hypotheses to be identified and tested using 'analytical induction', a method used to good effect in the work of Barrington Moore and his followers on the conditions enabling the emergence of democracies in different contexts. ${ }^{16}$ Applied to contemporary developing countries, this approach suggests a very different set of issues affecting the interaction between democracy, markets, and states that determines the nature of the relationship between democracy and development. Contemporary case study approaches to the study of democracy in developing countries provide a number of critical observations that define the starting point of our analysis.

First, they provide very consistent evidence that the politics of developing countries is dominated by patron-client factions. This is true for both democratic and authoritarian developing countries, implying that democracy in developing countries has features that are in general quite different from democracies in advanced countries. These features need to be understood if we are to elaborate the relationship between democracies in developing countries and the operation of markets and states relevant for understanding the prospects of development. Internal political stability in developing countries is maintained not primarily through fiscal policy, but through the largely off-budget and selective accommodation of factions organized along patronclient lines. Neither democracy nor authoritarianism appear to do away with the factional politics that underly these processes but serve only to modify the processes of accommodation, the numbers of factions that are accommodated, the terms of accommodation, and the ways in which factional competition is organized.

The common features of this type of politics have been collectively described as patrimonialism, clientelism, patron-client politics, and factional politics. The common features include the personalization of politics by faction leaders and the organization of politics as a competition between factions. The personalization of leadership is not based on traditional deference or the greater susceptibility of developing country 
societies to charisma, but is a rather 'modern' phenomenon in that faction leaders offer payoffs to those who support them. In turn, they capture the resources for making these payoffs by mobilizing their supporters in factions. In India, arguably the most successful democracy in a developing country, the deep inter-penetration of formal politics with informal structures of networks and factions has been powerfully described by Harriss-White and by Jenkins. ${ }^{17}$ In Africa, it used to be argued that neopatrimonialism was due to the absence of democracy, and authoritarianism allowed the continuation of personalized politics and the use of informal sources of power by the 'big men'. ${ }^{18}$ However, it is now more commonly recognized that neopatrimonialism and patron-client networks have survived the transition to democracy in Africa, and they continue to operate with relatively slight modifications. ${ }^{19}$

Secondly, parallel to these 'informal' political features of developing countries are a number of economic characteristics that set them apart from advanced economies. These characteristics include a larger 'informal' economy, widespread non-market accumulation processes (often described as primitive accumulation), and the use of state power to create a large range of rents that directly benefit the factions in power. ${ }^{20}$ These economic characteristics of developing countries set them apart from advanced countries. While democracy or authoritarianism can modify some of these characteristics, democratic and authoritarian developing countries are not significantly different in terms of these characteristics.

The 'informal economy', describes activities that are not formally regulated by the state. These activities comprise as much as 80 per cent of the economy of the relatively highly regulated (and democratic) India. ${ }^{21}$ This does not mean that large chunks of the economy are not regulated; it simply means that these areas are not regulated through the formal institutions of the state. These are precisely the areas where the regulatory and enforcement capacities of informal networks operating within and outside the state become critical for determining the types of economic activities that are viable and the ways in which rents are shared between producers, political factions and the formal state. This allows us to explain why entrepreneurs in developing countries are so willing to invest in factional political networks as an ongoing part of their normal commercial activities.

The use of political power in these ways to sustain accumulation in developing countries has attracted much attention from conventional economists who see this as evidence of rent seeking and political corruption. However, these activities are so systematic and widespread that we should look for structural reasons that may explain these features of developing countries. Once again, democracy or authoritarianism appears at best to modify the nature of these relationships and the ways in which political power is exercised. But democracy does not result in a significant change in these economic characteristics - in particular, it does not ensure the elimination of property rights instability, rent seeking, or political corruption in developing countries. $^{22}$

\section{Patron-Client Factions and Democracy in Developing Countries}

Given the prevalence of patron-client politics in developing countries, we need to investigate the factors that could explain the dominance and the implications for 
democratization. The analysis of patron-client politics in developing countries has drawn heavily on Weber's analysis of modern bureaucratic states as a foil against which to compare and assess developing country realities. Weber saw bureaucratic rule as the most rational form of organizing the social order, paralleling capitalism as the most rational form of organizing the economy. Bureaucratic rule and capitalism are therefore complementary forces that drove the secular rationalization that Weber saw as the most significant trend in contemporary history. We will see later that the appropriateness of Weber's conception of capitalism for understanding the emerging capitalisms in contemporary developing countries is questionable. ${ }^{23}$ But interestingly, even in terms of his own analysis, Weber saw a permanent tension between the logic of bureaucratic rule, which was inherently rational, and the logic of political leadership and charisma operating through democratic processes. This tension was unavoidable, and even necessary. It was indeed periodically necessary to revitalize bureaucratic rule by questioning and changing its objectives, without which it would have a tendency to ossify. ${ }^{24}$ Weber's analysis is therefore deliberately 'antinomical', showing the inner contradictions within his ideal types.

Neo-Weberians looking at developing countries have often ignored these subtleties and concentrated instead on the checklist of ideal-typical characteristics that a modern state should possess, characteristics that are most strikingly absent in developing countries. These idealtypical Weberian characteristics of the modern bureaucratic state include a formal, meritocratic bureaucratic structure that adheres to rules, is impersonal in its dealings with individual citizens, and represents a sharp separation of the private and public spheres. The operations of the typical developing country state in contrast are based on personalized exchanges between rulers and their factions, bureaucratic rules are regularly broken, and private interests are deeply penetrated in the public sphere represented by the bureaucracy. It appears that this could provide a compelling explanation of why a rational organization of social order does not appear to be taking place in developing countries. The absence of a rational bureaucratic struc ture could in turn explain why the development of capitalism has been impeded, as capitalism (in the Weberian conception) was the rational organization of the economic sphere. If the state was 'irrational' in its interventions in society, the development of capitalism could not but be affected.

\section{The Neo-Patrimonial Analysis}

The question that arises is why developing countries across the board should fail to meet the criteria of a Weberian bureaucratic state. Weber lived long before modern postcolonial developing countries emerged. His analysis was not about these countries at all, but rather about the contrast between 'rational' bureaucratic forms of governance seen in modern capitalism and traditional forms of authority in precapitalist societies. He identified patrimonial rule as one of the most important of these pre-capitalist forms of governance, where allegiance to a leader is based on personal loyalty and traditional legitimacy. ${ }^{25}$ However, it has become clear that in modern developing countries, patrimonial rule is not based on traditional legitimacy but rather on modern forms of exchange between patrons and clients, where clients agree to provide political support to the patron in exchange for payoffs that the patron can deliver by using political power to capture public resources. Based on this observation, Eisenstadt, Médard and others have developed the analysis of neo- 
patrimonialism, which seeks to explain the persistence of pre-modern state structures in developing countries, particularly in Africa. ${ }^{26}$

The key characteristic of the neo-patrimonial state is the personalization of power. The state is treated as an extension of the property of the leader, and the leader rules with the help of clients who get a payoff for their support. Clearly, formal rules are now less important than the informal networks upon which the leader's power is based. Indeed, formal rules are regularly flouted and corruption is widespread. In this sense, the neo-patrimonial state is the antithesis of bureaucratic rationality. In contrast to Weber's analysis of patrimonialism based on traditional legitimacy, the theorists of neo-patrimonialism argue that the basis of this new form of rule is the ability of leaders to personalize their power and avoid accountability. The democratic process now acquires a significant and very different role in the new analysis that it did not have in Weber's original analysis. Far from political leadership (expressed through the democratic process or otherwise) periodically coming into conflict with norms of bureaucratic rule, democracy in the neo-patrimonial model is the mechanism for undermining personalized rule and thereby allowing the emergence of rational bureaucratic forms of rule. The latter is in turn necessary for the deepening of the rational capitalist form of economic organization. Democracy thus emerges as the process that drives the emergence of capitalism in a way that was never suggested by Weber. Variants of this mechanism also appear in good governance models that have become popular in policy circles in the post-Cold War period. ${ }^{27}$

The problem with the neo-Weberian analysis is that it assumes that patron-client politics in developing countries is based on the intention of rulers and factions to personalize politics and that the se intentions do not have significant structural factors supporting them. Only if this assumption were true would it make sense to believe that subjecting the selection of rulers to greater transparency and competition would result in a weakening of personal political fiefdoms and the faction-based exercise of power. But, in fact, all the evidence of democratization in developing countries show that competition, transparency and electoral contests do very little to undermine the dominance of patron-client politics and of informal networks mediating the exercise of power. And since states remain informal, the extension of democracy does little to further the Weberian goal of constructing rational bureaucratic forms of rule. Thus, the puzzle of patron-client politics remains to be explained, particularly since most neo-patrimonial analysts rightly argue that political relationships in contemporary developing countries are 'modern' in the sense that leaders and followers are recognizably rational, and neo-patrimonialism is not based on traditional deference or culture. Deference for leaders is rarely more than superficial in most developing countries, and in addition, wide variations in culture appear to have little effect on the salience of patron-client networks. Thus, the evidence, some of which we have referred to earlier, requires us to look for other factors that could explain the dominance of variants of patron-client political organizations in developing countries, both democratic and authoritarian.

At the general level, political competition involves political organizations and interests competing to achieve distribution of income and assets that favour them. But the nature of the competing political organizations and the types of political strategies they employ appear to be significantly different between advanced and developing countries and this needs to be explained. I argue that without resorting to the 
functionalism of modernization theory, we can identify powerful economic factors that ensure that patron-client politics is rational for both leaders and organizationally powerful constituencies in developing countries. The difference between this and modernization theory will be discussed later, but a little reflection on the structural differences between advanced and developing capitalist countries tells us why the strategies of democratic political players are likely to be very different in the two. In advanced countries, a number of structural factors encourage the representation of generalized economic and class interests and the formulation of redistributive political demands within narrow bounds set by the limits of economic viability. In contrast, in developing countries, incentives favour the construction of pyramidal patron-client factions that compete for the capture of public resources in ways that are relatively unconstrained by economic viability considerations.

\section{$\underline{\text { Political Competition in Advanced Capitalist Countries }}$}

The economic characteristics of advanced capitalist countries have systemic effects on the types of political organizations that are likely to develop and the redistributive strategies they are likely to follow. These characteristics include the following. First, the level of economic development of advanced capitalist countries means they have a dominant capitalist sector, and this has significant implications for politics. In these economies, the welfare of most people, even if they are not capitalists, depends on the health of the capitalist sector. If they are workers, their employment and wage growth depends directly on the growth of the capitalist sector. If they are private sector professionals, the purchasers of their services are most often capitalists, or workers whose spending power depends on the health of the capitalist sector. And if they are public sector workers or professionals, their wages and salaries come from taxation, which again depends on how well the capitalist sector is performing. Thus, even though the substance of democratic politics is necessarily about achieving a different distribution of income and consumption from the one that the market might otherwise have produced, parties and interest groups soon come to understand that their success in mobilizing their constituents and delivering to them depends on maintaining the viability of the capitalist economy.

Within these limits, there is, of course, much room for variation. But the self-interest of class and interest groups in advanced country democracies tends to ensure that their political competition does not damage the viability of the capitalist system. As a result, democratic politics remains broadly pro-capitalist even though capitalists are necessarily in a minority. This does not mean that the process of politics in these countries is always smooth. There may be serious disagreements about what is feasible, and occasionally there may be deep crises when economic viability is adversely affected. But since all groups and classes suffer from policies that result in a shrinkage of the capitalist sector, and since the latter has a shared set of requirements for profitability and viability, powerful feedback mechanisms set in to constrain the demands of political groups when they exceed the tolerance of the capitalist sector. This feedback is particularly constraining when thoroughly anti-capitalist political movements in advanced countries are weak or absent, as they have been for most of the post-Second World War period, and even more so in the post-Cold War period.

Secondly, a high degree of economic development in advanced countries also means that politically active groups can address their redistributive concerns by seeking to 
influence or control the significant fiscal budget and/or by amending the state's considerable regulatory powers (for instance in regulating the financial sector or through health and safety regulations). In practice, this has meant that redistributive goals have been pursued through marginal changes in tax and subsidy rates, and marginal changes in regulatory structures, subject to the constraint of maintaining capitalist viability. Given the significant share of national income that is taxed in advanced countries and the very large national incomes, as well as the considerable scope and enforcement capacities of state regulation, these strategies have offered big rewards to groups engaging in political activity. At the same time, since fiscal and regulatory policies benefit everyone who shares these interests (whether class, regional or sectoral), a public case can always be made for the proposed changes. These characteristics ensure that redistributive agendas in advanced economies are likely to be organized around broadly-based organizations that represent the economic interests of large groups of individuals, who, in turn, share common economic interests or perspectives due to similar class positions in production, regional locations, or occupations. The actual delivery of subsidies and the implementation of regulations through the bureaucracy can then be achieved through impersonal, transparent, and bureaucratic processes in the Weberian sense. This does not mean that violations of these norms do not happen in advanced countries. There are always going to be incentives for corruption, theft and nepotism. These violations can be dealt with by enforcing bureaucratic norms and allowing open and transparent political competition.

Thirdly, and very importantly, while economic development allows certain types of redistributive goals to be achieved through the budget and through regulatory reform, it also rules out certain types of redistributive activity. This is because economic development means that most people who own assets or earn an income do so from economic activities that are viable. This means that not only do they produce economic surpluses, but that the surpluses are large enough to pay for the protection of the assets or the economic activities in question. This protection is typically organized not just through the employment of private protection for assets and activities (such as in the form of guards and lawyers). In addition, the protection of assets in advanced countries is primarily ensured through the state, which collects significant taxes from asset owners and income earners and uses these resources to provide an effective protection of valuable assets and activities.

Economists typically describe advanced countries as having stable property rights and a rule of law, with relatively low expropriation risk. ${ }^{28}$ While the statistical link between these variables and economic development is strong, the direction of causality is difficult to establish using statistics alone. The interesting question is whether property rights in advanced countries are stable because redistributive coalitions are sufficiently responsible not to cross the line between redistribution and expropriation, or are attempts at expropriation prevented by advanced country states because they have the effective power to enforce property rights and protect activities as a result of collecting significant amounts of taxes? In reality, both are likely to be true, but the voluntary responsibility of redistributive coalitions is unlikely to be sustained if coalitions knew they could get away with expropriation. Indeed, the economic ability of the state to enforce property rights and prevent expropriation is likely to be more important the more open the competition for redistribution. Rich countries can afford to have open democracies because the limits to expropriation are 
set not only by the self-interest of most coalitions (as discussed earlier) but also by the strong enforcement capacities of well-funded states.

\section{$\underline{\text { Political Competition in Developing Countries }}$}

In contrast, the conditions that enable transparent and impersonal redistributive political activity in advanced country democracies are almost entirely absent in developing countries. The less developed the country, the more significant is its divergence from the advanced country characteristics described earlier. In upper middle-income developing countries, a growing number of characteristics of advanced country economies begin to emerge and in these countries, the structural differences that affect politics are less stark compared to advanced countries. In our discussion, we will not dis tinguish between poorer and more advanced developing countries, although there is clearly a grey area between the two, taking into account the moderately high levels of economic development in middle-income countries.

The first contrast is that in developing countries, capitalism is not (yet) the dominant economic system and so the feedback mechanisms from the economic requirements of this sector to the organization of political demands are much weaker. While in the very long-term a decline in the growth prospects of the capitalist sector will impinge upon the income prospects of most people, in the short or even medium-term, a decline in the capitalist sector may not even be perceived by most people. This is because the majority of the population continue to live in subsistence agriculture or to survive through informal activities like petty production and trade, and their dependence on the performance of the capitalist sector is indirect at best. There are, therefore, much weaker constraints on the organization of mass movements based on populist demands as the participants in these movements do not see any direct effect on themselves of an immediate decline in the country's economic prospects.

Secondly, economic underdevelopment means that not only is the size of the national income small, the share of the formal capitalist sector is also small. Therefore, compared to advanced countries, the fiscal regime of the typical developing country taxes a smaller share of a much smaller national income. Indeed, in poorer developing countries, the budget is in deficit after paying the salaries of public employees, and even in the relatively more developed of the developing countries, the budget is in deficit after paying for the essential infrastructural investments. In most cases, much of public investment is financed by borrowing or by aid. Not surprisingly, the budget is usually not the primary focus of redistributive political activity in developing countries. Nor do redistributive coalitions primarily seek to achieve their goals by modifying the state's regulatory rules since much of the economy is in fact unregulated given the limited scope of the modern (capitalist) sector.

It is therefore not at all surprising that redistributive strategies in developing countries are typically not defined in terms of the interests of broad economic groups that could be met by transparent changes in fiscal or regulatory rules. Rather, political entrepreneurs in developing countries who want to achieve redistribution in their favour will rationally have to look for other strategies. Political entrepreneurs in most countries are likely to come primarily from the middle classes, but middle classes in developing countries have some special characteristics. Unlike the middle classes of advanced countries, who are mostly professionals and whose economic interests are 
closely tied to the capitalist sector, middle classes in developing countries consist of a collection of classes that can collectively be described as the 'intermediate' classes. ${ }^{29}$ Political entrepreneurs from different sections of the intermediate classes are unlikely to share common interests or to be constrained by the fate of the capitalist sector. The only viable redistributive strategy for developing country political entrepreneurs in the absence of any fiscal or regulatory space is to organize enough organizational muscle to be able to capture resources through a combination of fiscal, off-budget and even illegal means.

The intermediate classes include the educated classes with college or university education, the petty bourgeoisie, particularly those in the informal sector, and middling to rich peasants. This middle strata may be numerically small (possibly ten to 30 per cent of the population) and economically weak (compared to emerging capitalists), but in terms of legitimacy and organizational power, they are collectively the most powerful political group in most developing countries. This group produces the political entrepreneurs who lead both organized and informal politics in developing countries. Authoritarian regimes have to deal with them and accommodate the most powerful and vociferous groups. Equally, without their leadership and participation, electoral politics would be impossible. In practice, what we see most frequently in the democratic domain are contests between factions led and dominated by members of the intermediate classes. And even authoritarian regimes have to include enough factions led by intermediate class leaders within the ruling coalition to achieve political stability.

The economic structure of developing countries can also help explain the typical pyramidal structure of the factions led by the intermediate classes that emerge to participate in redistributive politics. As we have already pointed out, the intermediate classes consist of a vast group of people of differing social and economic status. Many of them are underemployed but organizationally powerful. Political entrepreneurs constructing factions can be expected to prefer faction members lower than themselves in social and economic status as these individuals will expect less in terms of payoffs for participating in the faction and lending their organizational weight to it. At the same time, faction leaders want to maximize their organizational power by including the most aggressive individuals and sub-factions, without whose support faction leaders will be unable to achieve their objectives. Pyramidal patronclient networks are then likely to emerge as the most rational form of organization for faction leaders at all levels of the social structure. Faction leaders promise rewards to their clients based on their organizational support, who in turn mobilize those below them, all the way down to foot soldiers who may only be mobilized during elections, strikes, riots and other political events, in return for very small payoffs. But factional membership and activity is rational at all levels of the faction since the payoffs available from the faction are always higher than those available from alternative types of political activity given the non-existence of budgetary resources and other economic features of the developing country economy referred to earlier. The difference between democratic and authoritarian regimes in this respect is the number of factions that the ruling coalition needs to accommodate for achieving the minimum political stability and the types of competition through which insiders and outsiders are selected. The ruling coalition is always a coalition of many different sub-factions, and irrespective of the type of regime, the ruling group has to make calculations of 
who to include and exclude using the same logic of cost and benefit as individual faction leaders. ${ }^{30}$

What political factions seek is not the construction of a coalition that can mobilize votes to allow a transparent renegotiation of taxes and subsidies, but a coalition that can mobilize organizational power at the lowest cost to the faction leader, to achieve a redistribution of assets and incomes using a combination of legal, quasi-legal, or even illegal methods. The organizational power of the faction is then used either directly to capture state power or to force an accommodation in the form of payoffs from the factions who are currently controlling the state. The faction's access to economic resources either in the form of revenue or in the power to grab valuable economic resources legally or otherwise is then used to benefit faction members all the way down the pyramid, though the payoffs may be very unequal for different levels of the faction.

While factions may use generalized arguments based on class, region, or interest in its public discourse, no-one in society is under any illusion that the faction is out to look after itself at the least cost in terms of paying off voters and others who need to be mobilized occasionally. When factions do not deliver on these generalized aims, broader social constituencies may grumble but they do not really expect anyone to deliver on the publicly stated general social goals. However, if factions cannot deliver acceptable payoffs to faction members, the leaders are likely to get into serious trouble. Factions rarely fear a general public revolt, given that no other political organization can deliver what the public wants. What factions actually fear is that their sub-factions may be bribed away by other factions and that the coalition may crumble. Indeed, this often happens and accounts for the frequent changes of government in developing countries that usually lead to no discernible changes in government policies, but do lead to different sets of individuals making money in turn. Given the opportunistic nature of factional membership and the shifting offers and counter-offers made by different factional leaders, it is possible to explain the extreme volatility in the factional politics of developing countries in a context where government policies are often remarkably constant.

Finally, developing countries are also different from advanced countries in a very significant respect: most of the economic assets and activities of a developing country (land, or traditional economic activities in the informal sector) are barely viable in that they produce very small surpluses, and, in general, do not produce enough to pay for their effective protection. It is difficult to explain why property rights are uniformly weak in every developing country if we ignore the fact that the effective protection of property rights is very expensive, and developing countries typically have pre-modern economic systems that do not use existing assets in ways that can generate large surpluses to pay for their protection. This has significant implications for the strategies that our pyramidal patron-client factions are likely to employ in pursuit of their redistributive agendas. If property rights and economic activities are not in general effectively protected in developing countries, they can easily become targets for the redistributive activity of coalitions seeking redistribution.

If we combine these observations, we find a list of developing country characteristics that are very different from advanced countries. Compared with the coalitions in advanced countries, redistributive coalitions in developing countries enjoy much 
greater latitude in the redistributive strategies they can follow because there is much weaker political feedback from the capitalist sector. Given this weak feedback from the productive sector, the strategies employed by redistributive coalitions in developing countries can vary very widely, from growth-enhancing strategies in some cases to growth-destroying strategies in others. Secondly, redistributive coalitions in developing countries have strong incentives to try and achieve redistribution through means that go well beyond marginal changes in taxation, spending, or regulation. This is because the relatively limited taxes paid by the small capitalist sector and the limited role of economic regulation cannot accommodate redistributive demands, however limited. Since public resources for accommodating broadly defined interests simply do not exist, political entrepreneurs seek to organize powerful groups that can assist their political accumulation and redistribution strategies. Given the structure of the intermediate classes, these groups are most likely to be the pyramidal patron-client factions that we observe. Finally, developing countries invariably have weak protection for property rights across the economy, which opens up a wide range of activities and assets to expropriation attempts. Even if assets are not totally expropriated by powerful redistributive coalitions, owners of assets, as well as many income earners, find they have to purchase protection from powerful factions if they are to continue gainful economic activities. Developing countries can thus range from situations close to anarchy where neo-patrimonialism acquires characteristics quite similar to warlordism to the relatively more normal variety of factionalism where property rights are unstable but are protected by patron-client coalitions at a price.

Thus, the economic structures of developing countries create strong incentives for the emergence of the very phenomenon that neo-Weberians identify as the variable explaining underdevelopment, namely the proliferation of patron-client networks, and the domination of personalized politics, variously described as clientelism, patrimonialism, and neo-patrimonialism. To that extent, the neo-Weberian argument stands reality on its head. The argument that neo-patrimonialism has to be addressed first in order to assist development sets developing countries an impossible target. To then argue that democratization will assist in achieving the weakening of neopatrimonial relationships is even more problematic as a policy prescription because the presence or absence of democracy has very little to do with the powerful incentives that drive the organization of patron-client politics. Indeed this approach can explain why patron-client politics continues to survive and thrive in democratic developing countries, an observation that has been referred to earlier in the section on evidence.

\section{Conclusion}

I have argued that both states and markets operate somewhat differently in advanced and developing countries. Developing country states are significantly penetrated by patron-client factions characterized by personalized leadership and the objectives of factional rent capture. Developing country markets are characterized by the underdevelopment of the capitalist sector, and the use of factional political power to protect assets and to support accumulation strategies based on the capture of assets using political power. These empirical observations are relevant for explaining the vulnerability of democracies in developing countries, for analysing the conditions 
under which democracies can survive and where it faces serious constraints, and for discussing the implications of democratic processes for economic development.

In contrast to the functionalist aspects of modernization theory, our analysis of the economics of developing countries suggests that while democracy is vulnerable in developing countries and is likely to operate very differently from advanced countries, democracy is not the cause of underdevelopment. Conversely, authoritarianism is not functionally required for development. In this sense, our analysis is fundamentally different from modernization theory. Instead, we argue that variants of patron-client politics are likely to characterize both democratic and authoritarian regimes in developing countries. If regime change in a particular country is observed to result in a change in performance, the causes have to be sought in the structure of patron-client factions in the particular country and the ways in which patterns of accommodation and competition are affected by democracy or its absence. The effects of democratization can therefore vary from country the country. In some countries, democratization could boost development, in others the reverse. ${ }^{31}$ But general results about the effects of democratization are certain to be misleading.

This analysis also challenges some of the core results of the neo-patrimonial analysis developed by neo-Weberians, and adopted in different forms in the good governance approach. In contrast to that analysis, this argument suggests that democratization does not undermine patrimonial politics. This is because the organization of personalized patron-client factions is driven not by the absence of democracy but, rather, by structural features of the economies of developing countries that make modern welfare-driven redistributive politics unviable. Nevertheless, it could be argued that since democracy is an end in itself, the support for democratization from the neo-Weberian analysis is desirable. However, this does not necessarily follow. We are not just referring to the selective way in which democratization is likely to be used by Western countries to target some developing country regimes and not others depending on their own geo-political interests. There is a much more serious concern.

While democratization is very desirable, the economies of developing countries are such that democratization is unlikely to deliver real benefits to a broad range of social groups till a minimum level of economic development has been achieved. The developmental challenge is how to accelerate that transition, and democratization, however desirable in even the most unpromising contexts, has little to do with accelerating the social transformations that developing countries require. The pace of the necessary social transformation depends on how the competition between factions affects the emergence of a capitalist sector, the acquisition of advance technologies by that sector, and its ability to begin to compete in global markets. Historical examples show that a number of different patterns of patron-client competition are compatible with the rapid emergence of such a capitalist sector, while many other patterns of factional competition act as a brake on this transformation. ${ }^{32}$ If accelerating the transformation was our objective, these patterns of factional politics should have been the target of analysis and of internal policy since they do not correlate in any simple way with the democracy-authoritarianism divide. The danger is that by prioritizing a series of reforms that have little to do with accelerating the development of a productive economy, policy-makers in developing countries are being encouraged to expend scarce reform capacities in areas that are unlikely to deliver results in the years to come. ${ }^{33}$ The outcome is likely to be not only slow growth in living standards 
in very poor economies, but also a much more serious disenchantment with what democracy has to offer, and a possible return to equally unpromising strategies of authoritarianism. A more realistic analysis of the operation of democracy in developing countries is necessary to counter both the excessive faith on democratization as well as to challenge the functionalist defence of authoritarianism coming from variants of modernization theory.

\section{$\underline{\text { Notes }}$}

${ }^{1}$ Kenneth J. Arrow, Social Choice and Individual Values Revised Edition, (New York: John Wiley and Sons, 1963), Dennis C. Mueller, Public Choice II: A Re vised Edition of Public Choice, (Cambridge: Cambridge University Press, 1989).

2 Jean Drèze and Amartya K. Sen, India: Economic Development and Social Opportunity, (New Delhi: Oxford University Press, 1995).

3 Raaj K. Sah and Joseph Stiglitz, 'Committees, Hierarchies and Polyarchies', Economic Journal, Vol. 98, No. 391 (1988), pp. 451-70.

4 Jean Drèze and Amartya K. Sen, Hunger and Public Action, (Oxford: Oxford University Press, 1989).

${ }^{5}$ Douglass C. North, Institutions, Institutional Change and Economic Performance, (Cambridge: Cambridge University Press, 1990), esp. pp. 107-110.

6 Mushtaq H. Khan, 'State Failure in Developing Countries and Strategies of Institutional Reform', in Bertil Tungodden, Nicholas Stern and Ivar Kolstad, (eds), Toward Pro-Poor Policies: Aid Institutions and Globalization, (Oxford: Oxford University Press and World Bank, 2004).

${ }^{7}$ North, Institutions, Institutional Change and Economic Performance, pp. 48-51.

${ }^{8}$ Mushtaq H. Khan, 'State Failure in Weak States: A Critique of New Institutionalist Explanations', in John Harriss, Janet Hunter and Colin M. Lewis, (eds), The New Institutional Economics and Third World Development, (London: Routledge, 1995).

${ }^{9}$ Rob Jenkins, Democratic Politics and Economic Reform in India, (Cambridge: Cambridge University Press, 2000).

${ }^{10}$ Mancur Olson, 'Dictatorship, Democracy and Development', in Mancur Olson and Satu Kähkönen, (eds), A Not-so-Dismal Science: A Broader View of Economies and Societies, (Oxford: Oxford University Press, 2000).

${ }^{11}$ Mancur Olson, The Rise and Decline of Nations, (London: Yale University Press, 1982). 
12 Adam Przeworski, Michael E. Alvarez, Jose Antonio Cheibub and Fernando Limongi, Democracy and Development: Political Institutions and Well-Being in the World, 1950-1990, (Cambridge: Cambridge University Press, 2000) pp. 78-88, Robert J. Barro, Determinants of Economic Growth: A Cross-Country Empirical Study, (Cambridge, Massachusetts: MIT Press, 1997), pp. 61-2.

13 Ross Burkhart and Michael Lewis-Beck, 'Comparative Democracy: The Economic Development Thesis', American Political Science Review, Vol. 88, (1994), pp. 903 910.

14 Przeworski, Alvarez, Cheibub and Limongi, Democracy and Development: Political Institutions and Well-Being in the World, 1950-1990, pp. 92-117.

${ }^{15}$ Ibid. p. 101.

16 Barrington Moore, Social Origins of Dictatorship and Democracy, (Harmondsworth: Penguin, 1991), Dietrich Rueschemeyer, Evelyne H. Stephens and John D. Stephens, Capitalist Development and Democracy, (Oxford: Polity, 1992).

17 Barbara Harriss-White, India Working: Essays on Society and Economy, (Cambridge: Cambridge University Press, 2003), Jenkins, Democratic Politics and Economic Reform in India.

18 Jean-François Médard, 'Corruption in the Neo-Patrimonial States of Sub-Saharan Africa', in Arnold J. Heidenheimer and Michael Johnston, (eds), Political Corruption: Concepts and Contexts. Third Edition, (New Brunswick: Transaction Publishers, 2002).

19 Patrick Chabal and Jean-Pascal Daloz, Africa Works: Disorder as Political Instrument, (Oxford and Indianapolis: James Currey and Indiana University Press, 1999).

20 Mushtaq H. Khan and K.S. Jomo (eds) Rents, Rent-Seeking and Economic Development: Theory and Evidence in Asia (Cambridge: Cambridge University Press, 2000), Harriss-White, India Working: Essays on Society and Economy.

${ }^{21}$ Harriss-White, India Working: Essays on Society and Economy, pp. 3-16.

${ }^{22}$ Ibid., particularly pp. 43-71 and 239-47.

23 For more on this see also Khan, 'State Failure in Developing Countries and Strategies of Institutional Reform', and Mushtaq H. Khan, 'Rent-seeking as Process', in Mushtaq H. Khan and K.S. Jomo, (eds), Rents, Rent-Seeking and Economic Development: Theory and Evidence in Asia, (Cambridge: Cambridge University Press, 2000).

${ }^{24}$ Wolfgang J. Mommsen, The Political and Social Theory of Max Weber, (Oxford: Polity Press, 1989) esp. pp. 109-20. 
${ }^{25}$ Max Weber, Economy and Society: An Outline of Interpretive Sociology. Edited by Guenther Roth and Claus Wittich. Vol. II, (Berkeley: University of California Press, 1978) pp. 1006-1110.

${ }^{26}$ Médard, 'Corruption in the Neo-Patrimonial States of Sub-Saharan Africa', Shmuel N. Eisenstadt, Traditional Patrimonialism and Modern Neo-Patrimonialism, (London: Sage, 1973).

27 See Mushtaq H. Khan, 'Evaluating the Emerging Palestinian State: 'Good Governance' versus 'Transformation Potential', in Mushtaq H. Khan, with, George Giacaman and Inge Amundsen, (eds), State Formation in Palestine: Viability and Governance during a Social Transformation, (London: RoutledgeCurzon, 2004) particularly pp. 18-35 and Khan, 'State Failure in Developing Countries and Strategies of Institutional Reform', for critical discussions of the good governance and neopatrimonial models.

${ }^{28}$ Christopher Clague, Philip Keefer, Stephen Knack and Mancur Olson, 'Democracy, Autocracy and the Institutions Supportive of Economic Growth', in Christopher Clague, (ed), Institutions and Economic Development: Growth and Governance in Less-Developed and Post-Socialist Countries, (Baltimore: The Johns Hopkins University Press, 1997), North, Institutions, Institutional Change and Economic Performance.

29 Intermediate classes are classes that are not asset rich to the extent that their incomes are primarily from rents, profits, interest, or other components of the economic surplus, nor are they so asset poor that their incomes primarily come from labour. See Mushtaq H. Khan, 'Class, Clientelism and Communal Politics in Bangladesh', in K.N. Panikkar, Terence J. Byres and Utsa Patnaik, (eds), The Making of History: Essays Presented to Irfan Habib, (New Delhi: Tulika, 2000) for a discussion and contrast with the definition of intermediate classes coming from Kalecki. The intermediate classes dominate the politics of developing countries because of their organizational power and social le gitimacy. Their roots can usually be traced back to colonial strategies of developing a local administrative class to manage the colony. See also Atul Kohli, 'Where Do High Growth Political Economies Come From? The Japanese Lineage of Korea's 'Developmental State', World Development, Vol. 22, No. 9 (1994), pp. 1269-1293.

30 See Mushtaq H. Khan, 'Fundamental Tensions in the Democratic Compromise', New Political Economy, Vol. 7, No. 2 (2002), pp. 275-277 and Khan, 'Class, Clientelism and Communal Politics in Bangladesh', for more details on the rational choices that faction leaders and followers are making.

31 For a more detailed analysis of the effects of different types of patron-client structures see Khan, 'Rent-seeking as Process'.

${ }^{32}$ Ibid., pp. 89-104.

33 For a detailed analysis of what this social transformation entails, see Khan, 'State Failure in Developing Countries and Strategies of Institutional Reform'. 